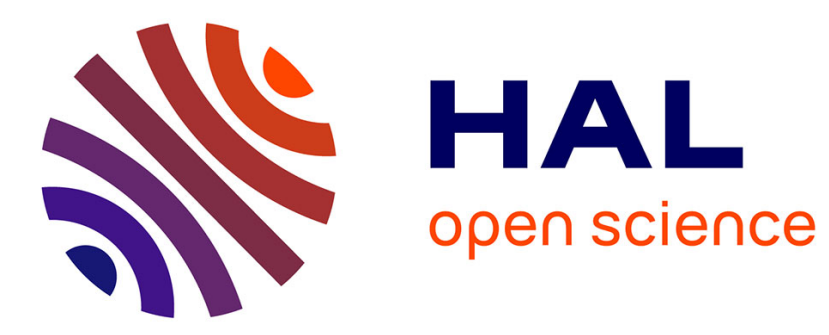

\title{
A new mid-Cretaceous fossil genus of stonefly (Plecoptera: Perlidae) from the Burmese amber
}

Corentin Jouault, Frédéric Legendre, Fabien L Condamine, Jean-Marc

Pouillon, Andre Nel

\section{To cite this version:}

Corentin Jouault, Frédéric Legendre, Fabien L Condamine, Jean-Marc Pouillon, Andre Nel. A new mid-Cretaceous fossil genus of stonefly (Plecoptera: Perlidae) from the Burmese amber. Cretaceous Research, 2022, 133, 133, pp.105138. 10.1016/j.cretres.2022.105138 . insu-03521497

\section{HAL Id: insu-03521497 https://hal-insu.archives-ouvertes.fr/insu-03521497}

Submitted on 11 Jan 2022

HAL is a multi-disciplinary open access archive for the deposit and dissemination of scientific research documents, whether they are published or not. The documents may come from teaching and research institutions in France or abroad, or from public or private research centers.
L'archive ouverte pluridisciplinaire HAL, est destinée au dépôt et à la diffusion de documents scientifiques de niveau recherche, publiés ou non, émanant des établissements d'enseignement et de recherche français ou étrangers, des laboratoires publics ou privés. 


\section{Journal Pre-proof}

A new mid-Cretaceous fossil genus of stonefly (Plecoptera: Perlidae) from the Burmese amber

Corentin Jouault, Frédéric Legendre, Fabien L. Condamine, Jean-Marc Pouillon, Andre Nel

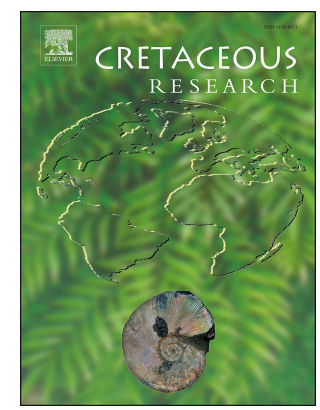

PII: S0195-6671(22)00002-7

DOI: https://doi.org/10.1016/j.cretres.2022.105138

Reference: YCRES 105138

To appear in: Cretaceous Research

Received Date: 5 October 2021

Revised Date: 19 December 2021

Accepted Date: 3 January 2022

Please cite this article as: Jouault, C., Legendre, F., Condamine, F.L., Pouillon, J.-M., Nel, A., A new mid-Cretaceous fossil genus of stonefly (Plecoptera: Perlidae) from the Burmese amber, Cretaceous Research, https://doi.org/10.1016/j.cretres.2022.105138.

This is a PDF file of an article that has undergone enhancements after acceptance, such as the addition of a cover page and metadata, and formatting for readability, but it is not yet the definitive version of record. This version will undergo additional copyediting, typesetting and review before it is published in its final form, but we are providing this version to give early visibility of the article. Please note that, during the production process, errors may be discovered which could affect the content, and all legal disclaimers that apply to the journal pertain.

(c) 2022 Elsevier Ltd. All rights reserved. 
1 A new mid-Cretaceous fossil genus of stonefly (Plecoptera: Perlidae) from the Burmese amber

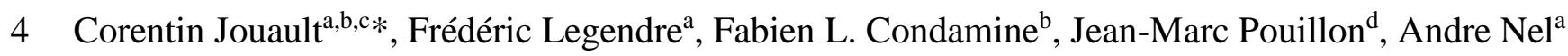

6 a Institut de Systématique, Évolution, Biodiversité (ISYEB), Muséum national d'Histoire naturelle, 7 CNRS, Sorbonne Université, EPHE, Université des Antilles, CP50, 57 rue Cuvier 75005 Paris, 8 France.

$9{ }^{\mathrm{b}}$ CNRS, UMR 5554 Institut des Sciences de l'Évolution de Montpellier, Place Eugène Bataillon, 10 34095, Montpellier, France.

$11{ }^{\mathrm{c}}$ Univ. Rennes, CNRS, Géosciences Rennes, UMR 6118, F-35000, Rennes, France.

12 d 178 rue des Plattières, F-38300 Nivolas-Vermelle, France.

$13 *$ Corresponding author.

14 E-mail address: jouaultc0@gmail.com

\section{ABSTRACT}

17 A new genus and species of stonefly is described and figured from the mid-Cretaceous Burmese 18 amber as $†$ Burmaperla pouilloni Jouault \& Nel gen. et sp. nov. The placement of this new genus 19 and species within the Perlidae is corroborated by an in-depth comparison of apomorphies. This 20 new species differs from all other Acroneuriinae from the mid-Cretaceous Burmese amber biota, 21 inter alia, owing to its wing venation with ScP reaching RA beyond ra-rp, RP with three branches, 22 MP partially fused with the upper branch of $\mathrm{CuA}, \mathrm{CuA}$ with four branches, its hammer nearly circu-

23 lar and its genitalia with paraprocts weakly sclerotized, abruptly upcurved, thinning towards the 24 apex and symmetrical. This new species increases the diversity of Acroneuriinae stoneflies in the 25 Burmese amber biota, and combined with the geological history of the Burmese terrane is used to 26 discuss the putative presence of Antarctoperlaria in mid-Cretaceous Burmese amber. 
28 Keywords:

29 Fossil record, gen. et sp. nov., Insecta, paleobiogeography, taxonomy

\section{1. Introduction}

32 The order Plecoptera, also called stoneflies because the adults are often found on rocks near streams

33 or ponds, is the sister group of a clade that would comprise all the other polyneopteran orders ex-

34 cept the more inclusive clade Zoraptera + Dermaptera (Wipfler et al., 2019: fig. 1). The current di-

35 versity of Plecoptera is greater than 3497 species (Fochetti and de Figueroa 2007). The number of

36 families of Plecoptera varies according to the authors but greatly benefits from the advances related

37 to the study of molecular data (South et al., 2021) despite this the position of some taxa remains

38 doubtful (e.g. Megaleuctra). The fossil record of Plecoptera represents ca. 300 species distributed in

39 ca. 25 families (sensu http://fossilworks.org/, last accessed September 29, 2021). Based on the fossil

40 record, the oldest described stem-groups Plecoptera date back to the Moscovian (ca. 314.6-311.45

41 Ma) from the Yanghugou Formation of China (Béthoux et al., 2011), and from France (ca. 308-306

42 Ma; Schubnel et al., 2019). Using molecular data, Letsch et al. (2021) inferred one of the most

43 comprehensive time-calibrated trees for extant Plecoptera, which filled an important gap on the di-

44 vergence time estimates of all the main clades of extant stoneflies. Relying on seven fossil calibra-

45 tions, this dated tree suggests that the crown-Plecoptera arose during the Guadalupian, ca. $265 \mathrm{Ma}$

46 (294.2 - 235.5 Ma, 95\% HPD) (Letsch et al., 2021: fig. 2).

Among the Plecoptera, the family Perlidae has its crown-group estimated in the Jurassic, ca.

$165 \mathrm{Ma}$, and is recovered as sister to the clade (Chloroperlidae + Perlodidae) (Letsch et al., 2021:

49 fig. 2). Their oldest representatives are known from the mid-Cretaceous Burmese amber (ca. $98 \mathrm{Ma}$ )

50 and some are confidently placed in the subfamily Acroneuriinae (e.g., Chen, 2018, 2019a,b). The

51 other subfamily, the Perlinae, has its oldest representatives known from Baltic amber (37.2-33.9 Ma)

52 (Pictet and Hagen, 1856). 
In this study, we describe a new genus and species of Perlidae based on a well-preserved

54 male specimen from the mid-Cretaceous Burmese amber. This discovery increases the diversity of

55 stoneflies documented from the Burmese amber biota.

\section{Material and methods}

58 The amber piece containing the specimen comes from the deposits of Noije Bum in the Hukawng

59 Valley $\left(26^{\circ} 29^{\prime}\right.$ N, $96^{\circ} 35^{\prime}$ E), Kachin State, Northern Myanmar (see detailed map in Grimaldi and

60 Ross, 2017: fig. 2). This amber deposit was located on the West Burma block (WBB) a terrane that

61 migrated from the south-east of Gondwana, across the Tethys Ocean during the Jurassic and Creta-

62 ceous and then collided with Asia (e.g. Seton et al., 2012). Radiometric data established an early

63 Cenomanian age (98.79 $\pm 0.62 \mathrm{Ma})$ for Kachin amber, based on zircons from volcanic clastes found

64 within the amber-bearing sediments (Shi et al., 2012). Some ammonites found in the amber-bearing

65 bed and within amber corroborate a late Albian-early Cenomanian age (Cruickshank and Ko, 2003;

66 Yu et al., 2019).

The holotype of $\dagger$ Burmaperla pouilloni gen. et sp. nov. (Figs. 1-3) is from the collection of one of us (JMP), and is complete and well preserved. The amber piece was polished to facilitate the observation of the specimen using a grinder polisher (Buehler EcoMet 30), and a thin silicon carbide sanding paper (grit size $=7000$ ). The specimen was examined and photographed with a Leica MZ APO with an attached Canon EOS 5D Mark II camera. All images are digitally stacked photomicrographic composites of several individual focal planes, which were obtained using Helicon Focus 6.7. The figures were composed with Adobe Illustrator CC2019 and Photoshop CC2019 soft-

74 ware. Wing venation nomenclature follows Béthoux (2005). The amber piece is housed in the 75 Musée d'Histoire Naturelle et d'Ethnographie (Colmar, France) under the collection number MHNE.2021.11.1. 
Published work and nomenclatural acts are registered in ZooBank (http://zoobank.org/, last 94 nine.

access: 1912 2021), with the following LSID (reference): urn:Isid:zoobank.org:pub:D6201846BF5F-46CB-A893-4F2DD7BAC430.

\section{Systematic Paleontology}

Order Plecoptera Burmeister, 1839

Suborder Arctoperlaria Zwick, 1973

Infra-order Systellognatha Enderlein, 1909

Superfamily Perloidea Latreille, 1802

Family Perlidae Latreille, 1802

Subfamily Acroneuriinae Klapálek, 1914

Genus Burmaperla Jouault \& Nel gen. nov.

urn:1sid:zoobank.org:act:A8E2792B-682B-474B-9FDC-B69ACB8FD4F0

Etymology. The genus name is a combination of the prefix 'burma' referring to the originating country of the amber piece (Myanmar) and Perla, type genus of the family Perlidae. Gender femi-

Type species. Burmaperla pouilloni sp. nov. Jouault \& Nel (only species included).

Diagnosis. Triocellate; pronotum slightly trapezoidal with broadly curved anterior and posterior corners, sutures distinct; first two tarsomeres shortest with euplantulae; forewing with ScP reaching RA beyond ra-rp; two extra crossvein beyond $\mathrm{ScP}$ and RA fusion point; at least eight crossveins between ScP and anterior margin; ScP+RA terminating well before wing apex; RP originating in basal third of forewing and with three branches; MP partially fused with upper branch of $\mathrm{CuA}$; $\mathrm{CuA}$ with four branches; AA2 with three branches; abdomen near half of body length; with all segments not extended; abdominal terga unmodified; posterior margin of sternum 9 rounded; hammer distinct, 
nearly circular, length $1.14 \times$ longer than wide; paraproct weakly sclerotized, abruptly upcurved,

thinning towards apex and symmetrical; cercomeres with long bristles.

Remark: A detailed discussion for the placement and comparison with other Acroneuriinae genera is available in the discussion part.

Burmaperla pouilloni Jouault \& Nel sp. nov.

109 (Figs. 1-3)

urn:lsid:zoobank.org:act:D9546CAA-D08F-49BC-97B0-7FA8411B12A9

111 Etymology. Named after Jean-Marc Pouillon, who donated the holotype. The species epithet is to

112 be treated as a noun in the genitive case.

113 Material. Holotype MHNE.2021.11.1 (a complete specimen preserved in an ovoid piece of amber

114 measuring $15 \times 19 \times 4 \mathrm{~mm}$ ), deposited at the Musée d'Histoire Naturelle et d'Ethnographie (Colmar, 115 France).

116 Locality and horizon: Noije Bum Hill, Hukawng Valley, Kachin State, Myanmar; upper Albian to 117 lower Cenomanian, mid-Cretaceous.

118 Diagnosis. As for the genus (vide supra).

119 Description. Macropterous; body length (excluding antennae and cerci) ca. $8.0 \mathrm{~mm}$, stout, generally 120 brown. Wings folded and overlapped on body so only forewings are visible. Dorsal aspect of termi121 nalia covered by wings but visible under microscope.

Head trapezoidal, ca. $1.05 \mathrm{~mm}$ long and $1.75 \mathrm{~mm}$ wide (eyes include) not overlapped byan-

123 terior part of pronotum, with an elliptical spot covering three ocelli and anterior half of head; two 124 posterior ocelli larger than anterior one; compound eyes rounded. Antenna brown and filiform, with 125 at least 45 antennomeres (hardly discernible basally since covered with bubbles), $0.81 \times$ as long as 126 body, each antennomere thinning towards apex. Maxillary palps long, with five visible palpomeres, 127 lengths from basal to apical ones (in mm): at least $0.07 ; 0.23 ; 0.43 ; 0.34 ; 0.20$. Labial palps with 128 three(?) palpomeres, length from basal to apical ones (in $\mathrm{mm}$ ): $>0.26 ; 0.40 ; 0.32$. 
Pronotum narrower than head, ca. $0.90 \mathrm{~mm}$ long and ca. $1.33 \mathrm{~mm}$ wide, slightly trapezoidal

130 with broadly curved corners, mostly brown except for a wide, pale median band. Dorsal part of

131 mesothorax and metathorax, similarly colored as pronotum, sclerotized except for median area,

132 nearly as wide as pronotum. Gill remnant maybe present, hidden inside bubbles. Furcal pit,

133 mesosternal Y-arm present; mesosternal Y-stem apparently present (not fully visible). Legs brown;

134 two tibia spurs present; fore femur ca. $0.42 \mathrm{~mm}$ wide and ca. $1.12 \mathrm{~mm}$ long, tibia ca. $0.17 \mathrm{~mm}$ wide

135 and ca. $1.5 \mathrm{~mm}$ long, tarsus ca. $0.52 \mathrm{~mm}$ long; mid femur ca. $0.42 \mathrm{~mm}$ wide and ca. $1.45 \mathrm{~mm}$ long,

136 tibia ca. $0.25 \mathrm{~mm}$ wide and ca. $1.67 \mathrm{~mm}$ long, tarsus ca. $0.62 \mathrm{~mm}$ long; hind femur ca. $0.45 \mathrm{~mm}$

137 wide and ca. $1.87 \mathrm{~mm}$ long, tibia ca. $0.29 \mathrm{~mm}$ wide and ca. $2.25 \mathrm{~mm}$ long, tarsus ca. $0.63 \mathrm{~mm}$ long;

138 first two tarsal segments shortest with conspicuous euplantulae; arolium broad and setose; tarsal 139 claws simple.

140 Wings hyaline, veins brown. Forewing length ca. $7.80 \mathrm{~mm}$; M forked at wing midlength; six 141 crossveins present between $\mathrm{M}$ and $\mathrm{CuA}$; $\mathrm{CuA}$ forked basal to fork of $\mathrm{M}$, with four branches; $\mathrm{CuP}$ 142 and AA1 simple; AA2 with three branches; area between $\mathrm{CuA}$ and $\mathrm{CuP}$ with five crossveins. Hind 143 wings hidden under forewings.

144 Abdomen length about half-length of body, with dark lateral surfaces and pale ventral sur145 face; posterolateral margins of each segment slightly extended. Lengths of sternites, in ventral view 146 from base to apex (in mm): $0.3 ; 0.35 ; 0.35 ; 0.37 ; 0.42 ; 0.40 ; 0.42 ; 0.9 ; 0.01$. Posterior margin of 147 sternum 9 rounded, posteromedially with an oval hammer. Paraproct weakly sclerotized, abruptly 148 upcurved, thinning towards apex and symmetrical. Cerci hairy and curved, with at least 10 cerco149 meres, basal cercomere much longer than other segments.

\section{4. Discussion}

152 This specimen displays several characters allowing a confident placement within the Perlidae and 153 Acroneuriinae. More precisely, a hammer on sternite 9 is an apomorphy of the Arctoperlaria (Zwick, 154 2000). The short first tarsomere, setose arolium, and small and weak mandibles are apomorphic 
characters supporting the subclade Systellognatha (Sroka et al., 2018; Zwick, 2000). The current classification of Plecoptera supports the superfamilies Perloidea and Pteronarcyoidea within the Systellognatha. Although Zwick (2000) proposed a series of apomorphic characters to define these two clades, they are all based either on the internal morphology or on nymph morphology and are therefore not visible on our specimen.

We do not place our specimen within the families included in the superfamily Pteronarcyoidea because it lacks laterally expanded arolium (Zwick, 2000), has a more reduced forewing venation (Béthoux, 2005), and a hammer/ventral vesicle that is not reduced. Additionally, wing venation character have been proposed to distinguish the Pteronarcyidae (Cui et al., 2016): numerous crossveins between $\mathrm{M}$ and $\mathrm{CuA}$ in distal half of wing, a character not recorded on this specimen. Similarly, we cannot place this specimen within the Styloperlidae since it lacks a dense setal brush on male sternite nine (replacing the vesicle or hammer) and lacks a X-shaped sclerotization normally recorded on the sternite 10 of male styloperlids (Zwick, 2000). The last pteronarcyoid family, the Peltoperlidae, is distinguishable from the other Plecoptera by a short head strongly inserted into the angulate prothorax (Chen and $\mathrm{Xu}, 2020)$, and by labial palps not visible in dorsal view (Fenoglio et al., 2021). These characters are not recorded on our specimen preventing its placement within the 171 Peltoperlidae.

The particular configuration of the tarsus, with a short basal tarsomere, has been considered differently according to the authors. This character is a synapomorphy of the Perloidea for Zwick

174 (1973), a synapomorphy of Perloidea with (Peltoperlidae + Styloperlidae) for Zwick (1980), and 175 independently derived in these lineages for Zwick (2000) and Nelson (2009). Therefore, there is no 176 doubt that this specimen belongs to the Perloidea (the other families being previously excluded).

177 Among the Perloidea (Perlodidae + Perlidae + Chloroperlidae), we can exclude affinities of our 178 specimen with the Chloroperlidae because it does not possess a slender body or an oval pronotum 179 (Zwick, 2000). Similarly, it cannot be placed within the Perlodidae because it does not possess 180 submental gills or lateral stylets of male epiproct, apomorphic characters of the Perlodinae (Zwick, 
2000). It differs from the Isoperlinae and Perlodinae in having a more developed wing venation

(e.g., RP with three branches). Based on the original diagnosis of the family (Klapálek, 1909), our

specimen differs from perlodid stoneflies in having a pronotum whose sides are not parallel, a character state found in numerous extant species (Huo and Du, 2021).

Therefore we place it within the family Perlidae, already well documented in Burmese am-

ber. We exclude affinities with the Perlinae because the specimen does not possess hemitergites 10 modified into anteriorly curved hooks; also the hammer is fully visible, while no hairbrush on mesal areas of abdominal sternites is visible (Zwick, 2000). Additionally, our specimen shows the apormorphic character of the Acroneuriinae, viz. the paraprocts transformed into anteriorly upcurved hooks (Zwick, 2000).

This specimen does not correspond to the putative imago of $\dagger$ Electroneuria ronwoodi Sroka et al., 2018 (known by a nymph), since it has short cerci while $\dagger$ Electroneuria ronwoodi has long ones. Zwick (1980) noticed a correlation between the length of cerci in nymphs and adults in the Systellognatha.

We cannot place the specimen in the genus $\uparrow$ Cretacroneuria Chen, 2020 since it has a different wing venation and genitalia configuration (Chen, 2020). Our specimen has a RP with three branches (vs. four in $\uparrow$ Cretacroneuria), its MP is fused with CuA for a short distance (vs. completely separated) and it has more m-cua crossveins. Additionally, the pronotum is less trapezoidal and the anterior corners are not angulate. The paraproct are not directed laterally but upcurved and hook-shaped (vs. digitiform in $\uparrow$ Cretacroneuria).

We do not assign the studied fossil to the genus $\uparrow$ Burmesoperla Chen, 2019 since it has a circular hammer (vs. C-shaped) and a forewing with MP and CuA partially fused (vs. completely separated) (Chen, 2019b).

Finally, Chen (2018) proposed a fossil tribe $\dagger$ Largusoperlini to accommodate the particular genus $\dagger$ Largusoperla Chen, Wang \& Du, 2018. He used the following characters to distinguish it 
shape; male paraprocts distinctly enlarged, asymmetrical; cercus with approximately 10 segments;

male tergum 9 with patches of long hairs; cleft of male tergum 10 at least in posterior half; male epiproct sclerite present' (Chen, 2018: 297). The proposed list of characters prevents us from placing the new fossil within the $\dagger$ Largusoperlini based on, at least, the hammer shape that is circular to slightly ovoid but not transverse, and the paraproct shape that is neither distinctly enlarged nor asymmetrical in the new fossil (Chen, 2018). Therefore, we proposed a new genus to accommodate this new specimen.

The description of Burmaperla pouilloni gen. et sp. nov. complements the relatively well-

215 diversified plecopteran fauna of the West Burma block (WBB). The current stonefly diversity on the West Burma block is however restricted to the sub-order Arctoperlaria, which is quite surprising considering the distribution of the extant representatives of the sub-order. In fact, the majority of Arctoperlaria are today found in the northern hemisphere, except the Notonemouridae, and are considered to be of Holarctic origin (Letsch et al., 2021: fig. 3). As a result, the colonization of West Burma block by the Arctoperlaria may have been late, when the WWB came closer to Laurasia during the Late Cretaceous (e.g. Westerweel et al., 2019), the alternative being that the Arctoperlaria were more widely distributed before the Cretaceous (Cui et al., 2018).

The path of the West Burma block through the Meso-Tethys Ocean-the West Burma block was originally located near the Australian block in east Gondwana during the Early Jurassic (e.g.

225 Seton et al., 2012) — is used as an argument to strengthen the assumption that West Burma block was isolated (an island) during its migration and that fauna transfers have taken place only before its separation or lately when it approached Laurasia. Therefore, early faunal inputs are supposed to have Gondwana origins (e.g. Poinar, 2018) and later inputs to be of Laurasia origins (e.g. Jouault, 2021). Consequently, some representatives of the Antarctoperlaria inhabiting the Gondwana may have colonized the WBB prior to its separation from Gondwana. This assumption would be corroborated by the presence of several Antarctoperlaria (e.g. Gondwanoperlidium: Pinto and Purper, 
233 fore, it seems possible that an antarctoperlarian fauna was trapped in Burmese amber but not yet

234 described.

236 5. Conclusion

237 Amber from northern Myanmar provides a unique glimpse to the paleodiversity of stoneflies during

238 the Cretaceous and particularly during the migration of the West Burma block (from South Gond-

239 wana to Asia during the Cretaceous). The current distribution of Plecoptera, their fossil record, and

240 the particular geological history of West Burma block suggest that the Antarctoperlaria may have

241 been present on WBB during the Cretaceous and trapped in amber but not yet described. The de-

242 scription of Burmaperla pouilloni gen. et sp. nov. also increases the diversity of Acroneuriinae

243 stoneflies and suggests that the subfamily was more diversified that previously thought. If the fossil

244 record of the order continues to grow, an analysis of the fossil record to decipher the evolutionary

245 dynamics of stoneflies over geological time will be needed to clarify the evolutionary history of the

246 order and better understand their diversification.

\section{Acknowledgements}

249 We warmly thank Dr. Pavel Sroka and an anonymous reviewer for their constructive and useful 250 comments on the early version of the manuscript. We also thank Dr. Eduardo Koutsoukos for man251 aging the article during the editing process. This work was partly contributed by CJ during his Ph.D. 252 project on the 'Impact des interactions biotiques et paléo-évènements sur la diversification des in253 sectes Neuropterida'.

\section{References}

256 Béthoux, O., 2005. Wing venation pattern of Plecoptera (Insecta: Neoptera). Illiesia 1, 52-81. 257 http://www2.pms-lj.si/illiesia/papers.html 
258 Béthoux, O., Cui, Y.Y., Kondratieff, B., Stark, B., Ren, D., 2011. At last, a Pennsylvanian stem-

259 stonefly (Plecoptera) discovered. BMC Evolutionary Biology 11, 248.

260 https://doi.org/10.1186/1471-2148-11-248

261 Chen, Z.T., 2018. First tergal structures for the fossil stonefly genus Largusoperla (Plecoptera: Per-

262 lidae): a new species and a new tribe of Acroneuriinae. Zootaxa 4462, 296-300.

263 https://doi.org/10.11646/zootaxa.4462.2.11

264 Chen, Z.T., 2019a. A remarkable new stonefly with bisexual structures in mid-Cretaceous Burmese

265 amber (Insecta: Perlidae). Cretaceous 104189.

266 https://doi.org/10.1016/j.cretres.2019.07.019

267 Chen, Z.T., 2019b. A new stonefly of Acroneuriinae (Plecoptera: Perlidae) from mid-Cretaceous 268 amber of northern Myanmar. Cretaceous Research 99, 128-132.

269 https://doi.org/10.1016/j.cretres.2019.02.020

270 Chen, Z.T., Xu, C.P., 2020. First Peltoperlidae (Insecta: Plecoptera) from mid-Cretaceous Burmese 271 amber. Cretaceous Research 114, 104506. https://doi.org/10.1016/j.cretres.2020.104506

272 Cruickshank, R.D., Ko, K., 2003. Geology of an amber locality in the Hukawng Valley, northern

273 Myanmar. Journal of Asian Earth Sciences 21, 441-455. https://doi.org/10.1016/S1367$2749120(02) 00044-5$

275 Cui, Y.Y., Béthoux, O., Kondratieff, B., Shih, C.K., Ren, D., 2016. The first fossil salmonfly (In276 secta: Plecoptera: Pteronarcyidae), back to the Middle Jurassic. BMC Evolutionary Biology 16, 277 1-14. https://doi.org/10.1186/s12862-016-0787-9

278 Cui, Y.Y., Ren, D., Béthoux, O., 2018. The Pangean journey of 'south forestflies' (Insecta: Plecop279 tera) revealed by their first fossils. Journal of Systematic Palaeontology 17, 255-268. $280 \quad$ https://doi.org/10.1080/14772019.2017.1407370

281 Fenoglio, S., Tierno de Figueroa, J.M., Fochetti, R., 2021. Chapitre 14. Ordre des Plecoptera (Plé282 coptères). pp. 341-350. In: Aberlenc, H.-P. (coord.). Les insectes du monde. Biodiversité, classi283 fication, clés de détermination des familles. Museo ed., Paris. 
284 Fochetti, R., de Figueroa, J.M.T., 2007. Global diversity of stoneflies (Plecoptera; Insecta) in

285 freshwater. In: Balian, E.V., Lévêque, C., Segers, H., Martens, K., (eds) Freshwater Animal Di286 versity Assessment. Developments in Hydrobiology, vol 198. Springer, Dordrecht. 287 https://doi.org/10.1007/978-1-4020-8259-7_39

288 Grimaldi, D.A., Ross, A.J., 2017. Extraordinary Lagerstätten in amber, with particular reference to 289 the Cretaceous of Burma. In: Fraser, N.C., Sues, H.D., (Eds.), Terrestrial Conservation La290 gerstätten: Windows into the Evolution of Life on Land. Dunedin Academic Press, Edinburgh, 291 pp. 287-342.

292 Huo, Q.B., Du, Y.Z., 2021. A new genus of Isoperlinae (Plecoptera: Perlodidae) from Tibet, China. Zootaxa 4996, 343-352. https://doi.org/10.11646/zootaxa.4996.2.8

294 Jouault, C., 2021. Mid-Cretaceous Burmese amber pelecinid wasps (Hymenoptera, Pelecinidae) 295 support the hypothesis of an Asian origin of the family. Annales de Paléontologie 107, 102464. https://doi.org/10.1016/j.annpal.2020.102464

297 Klapálek, F., 1909. In Klapálek, F., Grunberg, K., Hft. 8. Ephemerida, Plecoptera, Lepidoptera. In:

298 Brauer, A., Die Süsswasserfauna Deutschlands. Eine Exkursionsfauna 39

299 Letsch, H., Simon, S., Frandsen, P.B., Liu, S., Machida, R., Mayer, C., Misof, B., Niehuis, O., Zhou, 300 X., Wipfler, B., 2021. Combining molecular datasets with stronglyheterogeneous taxon coverage 301 enlightens the peculiar biogeographic history of stoneflies (Insecta: Plecoptera). Systematic Entomology 46, 952-967. https://doi.org/10.1111/syen.12505

303 Nelson, C.H., 2009. Surface ultrastructure and evolution of tarsal attachment structures in Plecop304 tera (Arthropoda: Hexapoda). Aquatic Insects 31 , $523-545$.

305 https://doi.org/10.1080/01650420802598210

306 Pictet, F.J., Hagen, H., 1856. Die im Bernstein befindlichen Neuropteren der Vorwelt. Die in Bern307 stein Befindlichen Organischen Reste der Vorwelt Gesammelt in Verbindung mit Mehreren

308 Bearbeitetet und Herausgegeben 2, 41-126. 
309

310

311

312

313

Pinto, I.D., Purper, I., 1978. A new genus and two new species of Plecopteran insects from the Triassic of Argentina. Pesquisas 10, 77-86. https://doi.org/10.22456/1807-9806.21776

Poinar, G., Jr. 2018. Burmese amber: evidence of Gondwanan origin and Cretaceous dispersion. Historical Biology 31, 1304-1309. https://doi.org/10.1080/08912963.2018.1446531

Riek, E.F., 1956. A re-examination of the mecopteroid and orthopteroid fossils (Insecta) from the Triassic beds at Denmark Hill, Queensland, with descriptions of further specimens. Australian Journal of Zoology 4, 98-110. https://doi.org/10.1071/ZO9560098

Riek, E.F., 1976a. A new collection of insects from the Upper Triassic of South Africa. Annals of the Natal Museum 22, 791-820. https://hdl.handle.net/10520/AJA03040798_608

Riek, E.F., 1976b. New Upper Permian insects from Natal, South Africa. Annals of the Natal Museum 22, 755-789. https://hdl.handle.net/10520/AJA03040798_613

Schubnel, T., Perdu, L., Roques, P., Garrouste, R., Nel, A., 2019. Two new stem-stoneflies discovered in the Pennsylvanian Avion locality, Pas-de-Calais, France (Insecta: 'Exopterygota'). Alcheringa: An Australasian Journal of Palaeontology 43, 430-435. https://doi.org/10.1080/03115518.2019.1569159

Seton, M., Müller, R.D., Zahirovic, S., Gaina, C., Torsvik, T., Shepard, G., Talsma, A., Gurnis, M., Turner, M., Maus, S., Chandler, M., 2012. Global continental and ocean basin reconstructions

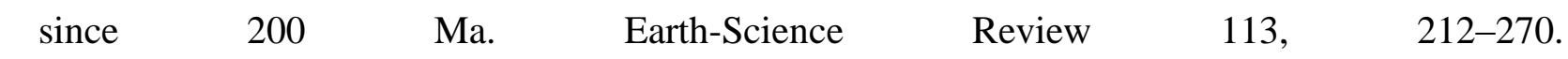
https://doi.org/10.1016/j.earscirev.2012.03.002

Shi, G.-H., Grimaldi, D.A., Harlow, G.E., Wang, J., Yang, M.-C., Lei, W.-Y., Li, Q.-L., Li, X.-H., 2012. Age constraint on Burmese amber based on U-Pb dating of zircons. Cretaceous Research 37, 155-163. https://doi.org/10.1016/j.cretres.2012.03.014

South, E.J., Skinner, R.K., DeWalt, R.E., Davis, M.A., Johnson, K.P., Teslenko, V.A., Lee, J.J., Malison, R.L., Hwang, J.M., Bae, Y.J., Myers, L.W., 2021. A New Family of Stoneflies (Insecta: Plecoptera), Kathroperlidae, fam. n., with a Phylogenomic Analysis of the Paraperlinae (Plecop- 
tera: Chloroperlidae), Insect Systematics and Diversity 5, ixab014.

335 https://doi.org/10.1093/isd/ixab014

336 Sroka, P., Staniczek, A.H., Kondratieff, B.C., 2018. 'Rolling' stoneflies (Insecta: Plecoptera) from

337 mid-Cretaceous Burmese amber. PeerJ 6, e5354. https://doi.org/10.7717/peerj.5354

338 Westerweel, J., Roperch, P., Licht, A., Dupont-Nivet, G., Win, Z., Poblete, F., Ruffet, G., Swe,

339 H.H., Thi, M.K., Aung, D.W., 2019. Burma Terrane part of the Trans-Tethyan arc during colli-

340 sion with India according to palaeomagnetic data. Nature Geoscience, 12, 863-868.

341 https://doi.org/10.1038/s41561-019-0443-2

342 Wipfler, B., Letsch, H., Frandsen, P.B., Kapli, P., Mayer, C., Bartel, D., Buckley, T.R., Donath, A., 343 Edgerly-Rooks, J.S., Fujita, M., Liu, S., Machida, R., Mashimo, Y., Misof, B., Niehuis, O., Pe344 ters, R.S., Petersen, M., Podsiadlowski, L., Schütte, K., Shimizu, S., Uchifune, T., Wilbrandt, J., 345 Yan, E., Zhou, X \& Simon, S. (2019) Evolutionary history of Polyneoptera and its implications 346 for our understanding of early winged insects. Proceedings of the National Academy of Sciences 347 of the United States of America 116, 3024-3029. https://doi.org/10.1073/pnas.1817794116

348 Yu, T.-T., Kelly, R., Mu, L., Ross, A., Kennedy, J., Broly, P., Xiai, F.-Y., Zhang, H.-C., Wang, B., 349 Dilcher, D., 2019. An ammonite trapped in Burmese amber. Proceedings of the National Acad350 emy of Sciences of the United States of America 116, 11345-11350. $351 \quad$ https://doi.org/10.1073/pnas.1821292116.

352 Zwick, P., 1973. Insecta Plecoptera. Phylogenetisches System und Katalog. In: Mertens, R., Hennig, 353 W., eds. Das Tierreich. Eine Zusammenfassung und Kennzeichnung der rezenten Tierformen. 354 Berlin: Walter de Gruyter. p. 465.

355 Zwick, P., 1980. Ordnung Plecoptera (Steinfliegen). In: Kukenthal, W. (ed.). Handbuch der Zoolo356 gie, 4 (2). Walter de Gruyter, Berlin, 26: 1-115.

357 Zwick, P., 2000. Phylogenetic system and zoogeography of the Plecoptera. Annual Review of En358 tomology 45, 709-746. https://doi.org/10.1146/annurev.ento.45.1.709 


\section{Figure captions}

362 Fig. 1. Burmaperla pouilloni Jouault \& Nel gen. et sp. nov., holotype MHNE.2021.11.1. Habitus. A, 363 dorsal view. B, ventral view. Scale bars $=1 \mathrm{~mm}$.

364 Fig. 2. Burmaperla pouilloni Jouault \& Nel gen. et sp. nov., holotype MHNE.2021.11.1. A, detailed 365 view of anterior part of body in dorsal view. B, detailed view of head in ventral view. Scale bars $366=0.5 \mathrm{~mm}$.

367 Fig. 3. Burmaperla pouilloni Jouault \& Nel gen. et sp. nov., holotype MHNE.2021.11.1. A, detailed 368 view of tarsus with euplantulae. B, detailed view of posterior part of body in ventral view. C, de369 tailed view of genitalia in postero-ventral view. D, line drawing of forewing venation with veins 370 labelled. Scale bars $=0.5 \mathrm{~mm}(\mathrm{~A}, \mathrm{~B}, \mathrm{C}) ; 1 \mathrm{~mm}(\mathrm{D})$. 


\section{Declaration of interests}

The authors declare that they have no known competing financial interests or personal relationships that could have appeared to influence the work reported in this paper. 


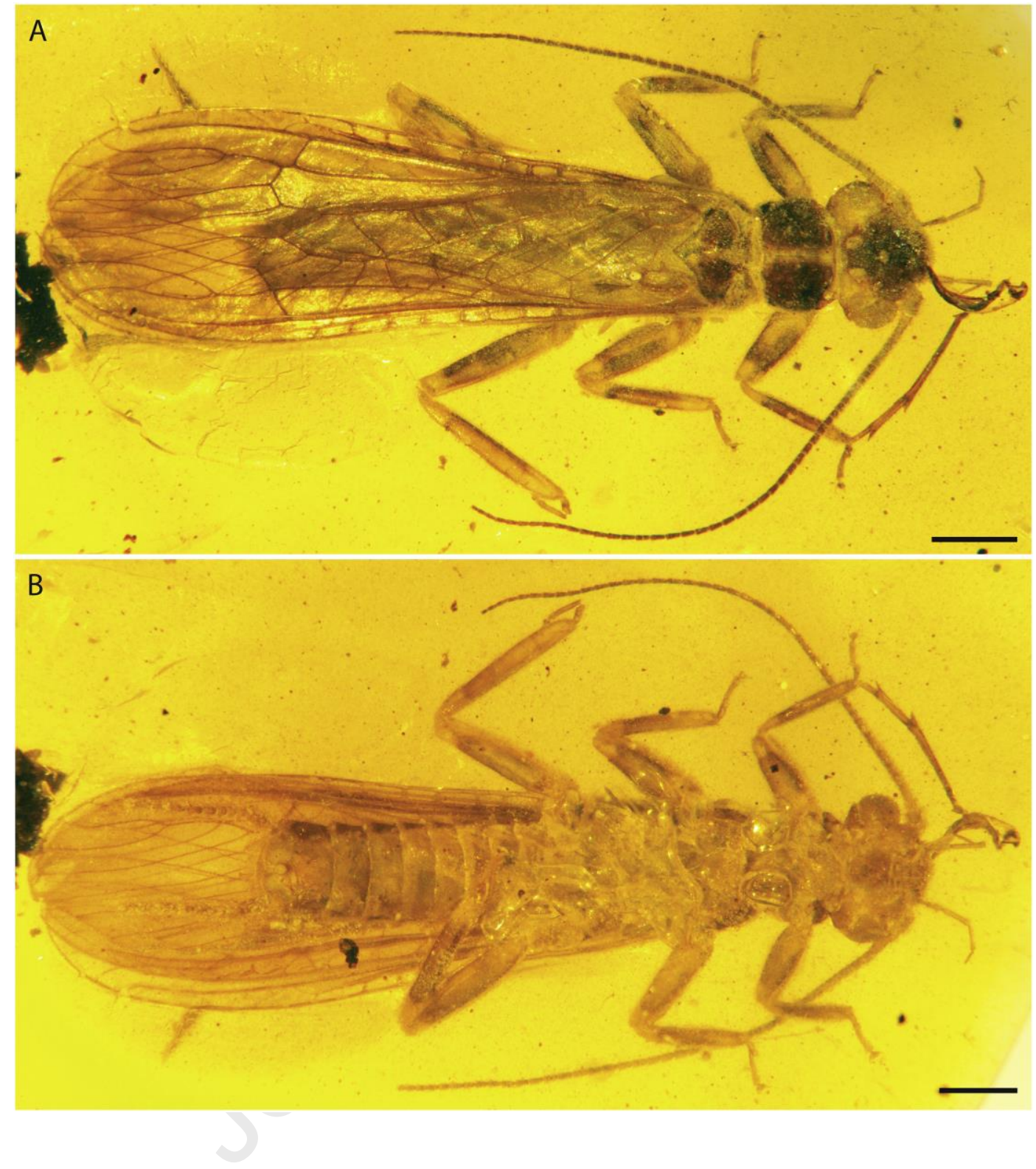



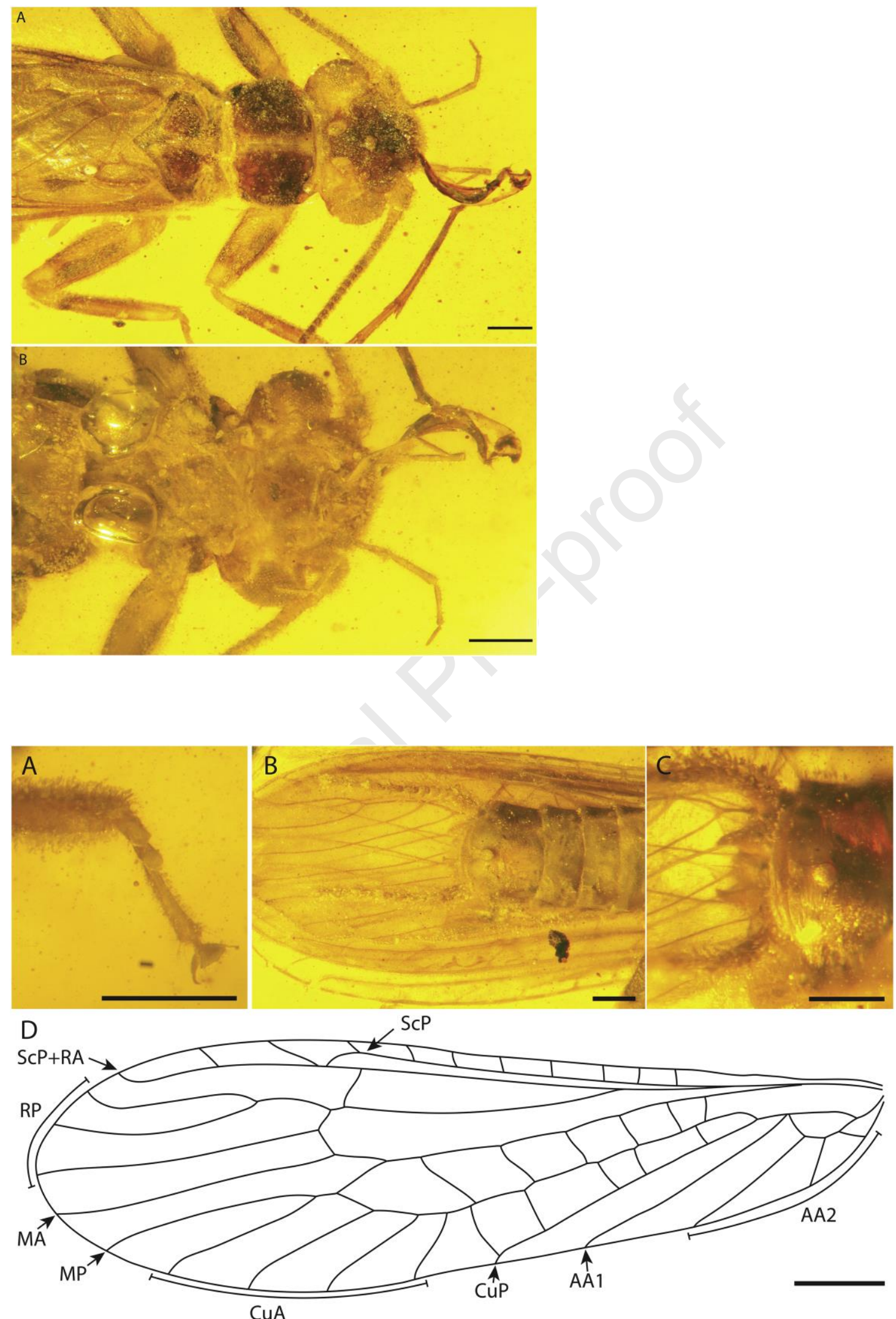